\title{
Transit-Oriented Development and Ridership at Kelana Jaya Line LRT Stations
}

\author{
Muhammad Ikram Baharom Shah'1, Jamalunlaili Abdullah', Kushairi Rashid²
}

\author{
1Faculty of Architecture, Planning and Surveying, \\ Universiti Teknologi MARA, Shah Alam, Selangor, Malaysia. \\ 2Faculty of Architecture, Planning and Surveying, \\ Universiti Teknologi MARA Perak Branch,Sri Iskandar, Perak, Malaysia.
}

Ikram@uitm.edu.my, jamal858@uitm.edu.my, kushai575@yahoo.com.my

Tel: 601126433117

\begin{abstract}
Transit-Oriented Developments (TOD) which promote high density and mixed-use development around transit centers may affect the success of mass rapid transit. This paper analyses the possible relationship between land use around the stations and the number of riders using the LRT Kelana Jaya Line in Klang Valley, Malaysia as the case study. It compares the ridership data with Land Use Public Transport Accessibility Index (LUPTAI) for ten selected stations. This study does not

find a strong correlation between LUPTAI and ridership, perhaps since almost all land around the stations is already developed and the development intensity is not factored in.
\end{abstract}

Keywords: Transit-oriented development; land use; ridership

eISSN: 2398-42870 2020. The Authors. Published for AMER ABRA cE-Bs by e-International Publishing House, Ltd., UK. This is an open access article under the CC BYNC-ND license (http://creativecommons.org/licenses/by-nc-nd/4.0). Peer-review under responsibility of AMER (Association of Malaysian Environment-Behaviour Researchers), ABRA (Association of Behavioural Researchers on Asians) and CE-Bs (Centre for Environment-Behaviour Studies), Faculty of Architecture, Planning \& Surveying, Universiti Teknologi MARA, Malaysia.

DOI: https://doi.org/10.21834/ebpj.v5i14.2196

\subsection{Introduction}

Transit-Oriented Development (TOD) has become a popular solution to optimize the use of land around transit stations and to tackle urban transportation issues. TOD is a land-use strategy that focuses on enhancing transit accessibility and also encouraging compact, high density, and mixed-use development, within an easy walk of a transit station. A typical TOD neighborhood has a diameter of a quarter to a half-mile $(400 \mathrm{~m}-800 \mathrm{~m}$ ) which represents pedestrian scale distances (5-10 minutes' walk). In Malaysia, the government has been promoting the development of TOD around selected transit stations. As such, the $11^{\text {th }}$ Malaysian Plan, National Physical Plan 3 (RFN 3), National Urbanization Policies 2 (DPN 2), and Planning Design Guidelines for Compact, Livable, and Smart Development include policies and strategies related to TOD. These strategies mainly focus on encouraging public transportation uses, walking, and cycling as alternatives to private motor vehicles.

Transit-Oriented Development projects in Malaysia are mainly located in the Kuala Lumpur Metropolitan area since the Mass Rapid Transit (MRT) and Light Rail Transit (LRT) are found here. The development of KL Sentral, Terminal Bersepadu Selatan, and other transit stations has spurred economic developments around the stations.

Kuala Lumpur City Plan (KLCP) 2020 has identified Transit Planning Zone (TPZ) to areas within 400m of a transit (Light Rail Transit, KTM Komuter, Monorail, or Bus Rapid Transit) station to encourage more TOD development. The importance of TOD in KLCP is to increase transit ridership as well as to promote development and investment. The essential element of all these TODs is the proximity of stations to residential areas, places of employment, schools, health services, and other public transports, thereby enhancing mobility

eISSN: 2398-42870 2020. The Authors. Published for AMER ABRA cE-Bs by e-International Publishing House, Ltd., UK. This is an open access article under the CC BYNC-ND license (http://creativecommons.org/licenses/by-nc-nd/4.0). Peer-review under responsibility of AMER (Association of Malaysian Environment-Behaviour Researchers), ABRA (Association of Behavioural Researchers on Asians) and cE-Bs (Centre for Environment-Behaviour Studies), Faculty of Architecture, Planning \& Surveying, Universiti Teknologi MARA, Malaysia.

DOI: https://doi.org/10.21834/ebpj.v5i14.2196 
and productivity of the urban population. In addition to Kuala Lumpur City Hall, other municipalities around Kuala Lumpur such as Petaling Jaya City Hall and Subang Jaya Municipal Council where the MRT and LRT traverse, have also promoted the development of TOD within their localities.

\subsection{Aim of the study}

This study aims to analyze the relationship between TOD and ridership of selected LRT stations along the Kelana Jaya Line in Metropolitan Kuala Lumpur.

\subsection{Objectives of the study}

To achieve the aim, two main objectives of this study are to assess the TOD level of the selectedstations using the Land Use and Public Transportation Accessibility Index (LUPTAI) and determining the number of ridership in each station based the on-site survey. It tries to determine if there are correlations between LUPTAI and the ridership numbers.

\subsection{Literature Review}

\subsection{Transit-Oriented Development (TOD)}

Urban sprawl and auto mobilization has led to an increase in the number of journeys made by private motorized vehicles, leading to increased congestion and greenhouse gas emissions. Sustainable development which includes coordination between land use planning and transportation system planning is the way to arrest this phenomenon. Transit-Oriented Development (TOD) which integrates the MRT system and land use development is a viable tool for achieving said coordination (Aditya et. al., 2016; Ding et.al., 2017).TOD devises urban development plans based on public transportation systems to enhance the sustainability of MRT systems, land-use efficiency, and traffic operation effectiveness (Litman, 2016).

Transit-oriented development (TOD) is a land-use strategy that focuses on enhancing accessibility by encouraging compact, high density, mixed-use development within an easy walk of a transit station (Langlois et. al., 2016). A typical TOD neighborhood has a diameter of a quarter to a half-mile $(400 \mathrm{~m}-800 \mathrm{~m})$ which represents pedestrian scale distances (5-10 minutes' walk). In urban planning, TOD maximizes the amount of residential, business, and leisure space within walking distance of public transport. The Centre for TransitOriented Development believes that a TOD project should increase 'location efficiency' so people can walk and bike and take transit, boosting transit ridership and minimizing traffic. According to Sung and Oh (2011), land use mix, street network, urban design, and an overall pedestrian-friendly area around the stations are the most important factors that may affect the ridership density. The influencing factors on Taipei metro station ridership covered four dimensions: land use, social-economic, accessibility, and network structure (Yuxin H et. al., 2018).

TOD is a planning initiative to promote and accelerate the walkable, mix-use communities around rail stations. TOD provides compact, mixed-use development with convenient access to employment and facilities for mass transit riders. In addition to diversity, comfortable and safe access to transit is rather important for TOD residents (Pongprasert and Kubota, 2018). Therefore, an accurate selection of station areas is paramount: station areas need to adequately correspond to TOD characteristics in terms of urban design and walkability. TOD also focuses on urban growth around transit facilities and leverages on transit investments to help produce substantial benefits such as walkable communities, improved access to jobs and economic opportunities, reduced motor traffic congestion, less air pollution, and lower greenhouse gas emissions (Buang.S, 2018).

According to the Transit-Oriented Development Institute, United States (2016), some of the benefits of TOD are;

i. High quality of life to live, work, and play

ii. Greater mobility and accessibility

iii. Increased transit ridership such as LRT

iv. Reduced traffic congestion

v. Reduced household spending on transportation, resulting in more affordable housing

vi. An active and healthier lifestyle with more walking and fewer stress

vii. Higher, more stable property values

viii. Increased foot traffic and customers for area businesses

ix. Reduced dependence on foreign oil, reduced pollution, and environmental damage

$x$. Reduced incentive to sprawl and increased incentive for compact development

xi. Less expensive than building roads and sprawl

xii. Enhanced ability to maintain economic competitiveness

\subsection{Ridership}

Table 1 shows some of the factors that influence transit ridership. Among the factors that influence ridership are land use and the built environment around the stations. Thus, a TOD station is expected to attract higher ridership for the transit service. 
Table1: Factors that influence ridership.

\begin{tabular}{ll}
\hline \multicolumn{1}{c}{ Factors That Influence Ridership } & Authors / Researchers \\
\hline $\begin{array}{l}\text { Commercial and governmental land uses, bus connectivity, and transfer stations are all associated with } \\
\text { station ridership during morning peak hours }\end{array}$ & (Chan and Miranda-Moreno, \\
\hline $\begin{array}{l}\text { Densely distributed offices nearby metro stations are key factors affecting commuting ridership, so } \\
\text { relevant strategies are necessary to control traffic, plan TOD and balance commuting ridership. }\end{array}$ & $\begin{array}{l}\text { (Hoogendoorn, and W. } \\
\text { Daamen, 2013). }\end{array}$ \\
\hline $\begin{array}{l}\text { The influencing factors on Taipei metro station ridership covered four dimensions: land use, socio- } \\
\text { economic, accessibility and network structure }\end{array}$ & (Yuxin H et. al., 2018) \\
\hline $\begin{array}{l}\text { Reliable transit service is essential to attracting and retaining riders. } \\
\text { Porosity, a pedestrian connectivity measure, is significantly positively associated with higher station } \\
\text { ridership. }\end{array}$ & (Levinson, 2005). \\
\hline $\begin{array}{l}\text { TOD may increase transit ridership, increase walking and biking, and decrease the share of automobile } \\
\text { trips. The design and mixed-use features of TOD may reduce both work and non-work automobile trips. }\end{array}$ & (Lund et. al.,2004). \\
\hline
\end{tabular}

\subsection{Land Use and Public Transport Accessibility Index (LUPTAl).}

Land Use and Public Transport Accessibility Index (LUPTAI) is a tool developed in 2006 to measure how easy it is to access common destinations such as residential, health, education, commercial, and offices by walking or using public transport. LUPTAl is an originbased accessibility model. This information relating to the land uses Destinations (LUDs), the road or pedestrian network, and the public transport network. The four-color scale shows the levels of access for an area, highlighting areas of high, moderate, low, and weak accessibility. Thus, the land use and distance from the transit stations are the main determining factors for LUPTAI (Yigitcanlar, et.al. 2007)

\subsection{Methodology}

\subsection{Study Area}

The Klang Valley (Kuala Lumpur Metropolitan) currently has the most extensive rail transit system in Malaysia. As shown in Figure 1, there are currently 9 train or transit lines being operated in the Klang Valley. MRT2, as well as LRT 3, are currently being built. The rail networks that serve Klang Valley include KTMB Komuter, KLIA Transit / Ekspress, LRT Sri Petaling Line, LRT Kelana Jaya Line, KL Monorail, and the newly opened MRT Sungai Buloh-Kajang Line.

This research focuses on the Kelana Jaya line LRT. It runs from Putra Heights in the south of Kuala Lumpur through Kelana Jaya to Gombak, which comprises $46.4 \mathrm{~km}$ of grade-separated tracks with 37 stations. It is one of the most established lines with a high amount of ridership. This research evaluates the 10 stations along the line which include Lembah Subang (KJ25), Ara Damansara (KJ26), Glenmarie (KJ27), Subang Jaya (KJ28), SS15 (KJ29), USJ7 (KJ31), Taipan (KJ32), Wawasan (KJ33), USJ21 (KJ34), and Alam Megah (KJ35). These stations are within the jurisdictions of Petaling Jaya City Hall (MBPJ) and Subang Jaya Municipal Council (MPSJ).

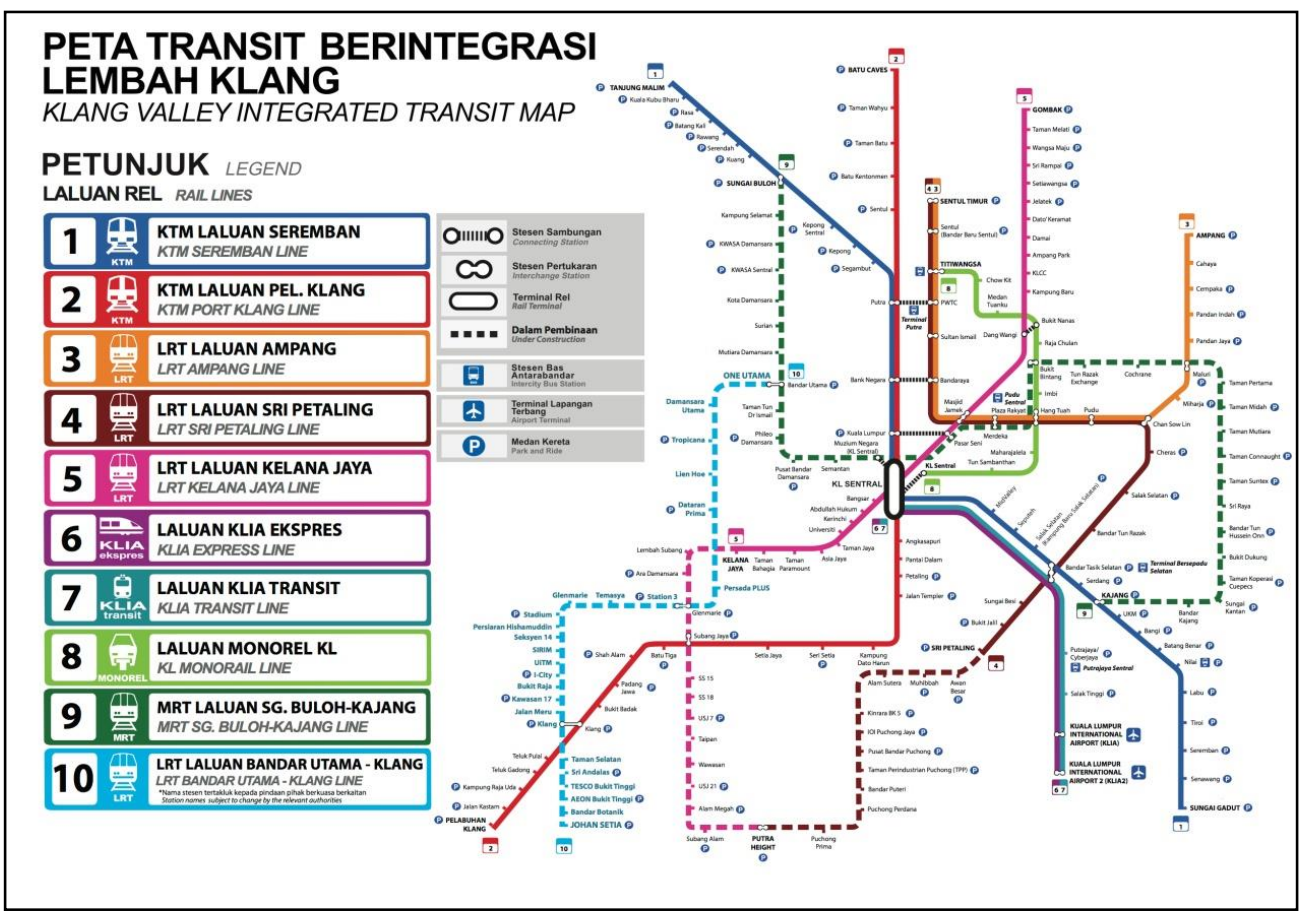

Figure 1: The rail network in Klang Valley, Malaysia 


\subsection{Data Collection and Analysis}

The data used in this study consists of primary and secondary data. The two main sets of data are LRT ridership and land use data around the stations. The primary data of ridership is obtained through manual counting of riders who entered and exited the selected stations by enumerators. The counting was done from 8.00 am until 10 am and from 12.00 noon until 2 pm on weekdays in all 10 selected stations. Due to time and enumerators limitation, the counting was

conducted during these periods only which may affect the findings since those who go to commercial areas are likely to ride the LRT at other times and during the weekend as well.

For spatial development around the stations, MBPJ and MPSJ provided secondary data of land use within 500 meters from the stations. These data were then verified on-site through observations of physical development. The land use data is analyzed and calculated using the Land Use and Public Transport Accessibility Index (LUPTAI).

The land use survey covers the facilities and the surrounding area of Lembah Subang (KJ25), Ara Damansara (KJ26), Glenmarie (KJ27), Subang Jaya (KJ28), SS15 (KJ29), USJ7 (KJ31), Taipan (KJ32), Wawasan (KJ33), USJ21 (KJ34) and Alam Megah (KJ35) stations. The analysis determines whether land use is commercial, residential,

or public facilities for all the 10 selected LRT stations. The location of this land uses is grouped into four groups of impacts based on the strength of locations (refer to Table 3).

i. High (Green in Table 2) - for land use within a 100-meter radius within the station which has the strongest impact on ridership for that station.

ii. Moderate (Yellow in Table 2) - for land use between 100 - 200-meter radius from the LRT station which is likely to have a moderate impact on ridership.

iii. Low (Orange in Table 2) - for land use between 200 - 300-meter radiuses where people start to calculate whether they should walk on a sunny day or using another mode of transportation.

iv. Weak (Red in Table 2) - For land use between 300 to the 500 - meter radius which is likely to have a weak impact on LRT ridership among the four groups due to the distance.

In the LUPTAI the calculation, each group is given different weightage ranging from 0.4 for the high impact group to 0.1 for the weak impact group (Table 2). The weightage is multiplied with land use of that area. One of the key outputs of the LUPTAI project is a composite index that provides a measure of the level of accessibility for all the land use destinations considered within the analysis. The composite index is based on a rudimentary weighting that residential, commercial, and public facilities have equal value in influencing the overall composite index. That means there is no distinguishing whether commercial land use has a greater impact on ridership than residential use. Thus, the study employs basic LUD data which do not consider the intensity of the development.

\subsection{Findings \\ 4.1 Land use}

The result of the land use survey distribution in Table 2 shows that almost all land-use patterns

within 500 meters of the LRT stations are commercial and residential areas. Some such as Taipan, Wawasan, and USJ21 stations are dominated by residential land use, while others are a mix of residential and commercial uses. This land-use data distribution will be used to calculate the LUPTAI for each station.

Table 2: Land use distribution component around LRT stations

\begin{tabular}{|c|c|c|c|c|c|c|c|}
\hline \multirow{3}{*}{ LRT STATION } & \multicolumn{6}{|c|}{ LAND USE } & \multirow{3}{*}{ Total $\%$} \\
\hline & \multicolumn{2}{|c|}{ Residential } & \multicolumn{2}{|c|}{ Commercial } & \multicolumn{2}{|c|}{ Public Facilities } & \\
\hline & Area $(\mathrm{Km})$ & $\%$ & Area $(\mathrm{Km})$ & $\%$ & Area $(\mathrm{Km})$ & $\%$ & \\
\hline LEMBAH SUBANG & 0.462 & 55.66 & 0.283 & 34.10 & 0.085 & 10.24 & 100 \\
\hline ARA DAMANSARA & 0.305 & 35.46 & 0.340 & 39.54 & 0.215 & 25 & 100 \\
\hline GLENMARIE & 0.255 & 49.04 & 0.220 & 42.31 & 0.045 & 8.65 & 100 \\
\hline SUBANG JAYA & 0.270 & 51.92 & 0.220 & 42.31 & 0.030 & 5.77 & 100 \\
\hline SS15 & 0.510 & 65.81 & 0.200 & 25.80 & 0.065 & 8.39 & 100 \\
\hline USJ 7 & 0.330 & 52.80 & 0.240 & 38.40 & 0.055 & 8.80 & 100 \\
\hline TAIPAN & 0.420 & 70.59 & 0.110 & 18.49 & 0.065 & 10.92 & 100 \\
\hline WAWASAN & 0.600 & 80.00 & 0.080 & 10.67 & 0.070 & 9.33 & 100 \\
\hline USJ 21 & 0.670 & 84.28 & 0.030 & 3.77 & 0.095 & 11.95 & 100 \\
\hline ALAM MEGAH & 0.310 & 62 & 0.045 & 9 & 0.145 & 29 & 100 \\
\hline
\end{tabular}


4.2 Land Use and Public Transport Accessibility Index (LUPTAI)

The land-use data comprising of residential, commercial, and public facilities land uses are calculated based on the distances of the uses from the stations (Table 3). Thus, stations that have most of the land closest to them developed as commercial, residential, or public facilities will tend to have higher LUPTAI compared to areas around stations that have not been developed yet. The results show that LUPTAI for all stations does not differ much from one another. Most tend to have LUPTAl readings of 19 and 20 with the highest at Wawasan station (KJ33) with an index of 24.3. This is perhaps because almost all areas around the stations have been developed since they are in relatively mature urban areas. Thus, not much variation in terms of LUPTAI among the stations; most tend to have commercial or residential uses. Wawasan station has the highest score since it has a larger percentage of urban land use within 100 meters from the stations as shown by the green color in Table 3 and Figure 2. Figure 3 shows the land use within the 500 -meters radius of the ten selected stations.

Table 3: LUPTAI Index of Kelana Jaya Line LRT Stations

\begin{tabular}{|c|c|c|c|c|c|c|}
\hline \multirow{2}{*}{ Station } & LRT Line & Weak & Low & Moderate & High & LUPTAI \\
\hline & Score & 0.1 & 0.2 & 0.3 & 0.4 & \\
\hline LEMBAH SUBANG & KJ25 & 18.65 & 61.12 & 12.76 & 7.47 & 20.88 \\
\hline ARA DAMANSARA & KJ26 & 40 & 20.78 & 30.4 & 8.82 & 20.79 \\
\hline GLENMARIE & KJ27 & 37.48 & 35.33 & 24.16 & 3.03 & 19.19 \\
\hline SUBANG JAYA & KJ28 & 29.26 & 53.68 & 9.15 & 7.91 & 19.55 \\
\hline SS15 & KJ29 & 16.94 & 60.69 & 17.70 & 4.64 & 20.98 \\
\hline USJ7 & KJ31 & 37.75 & 45.39 & 12.06 & 4.8 & 18.37 \\
\hline TAIPAN & KJ32 & 31.18 & 46.62 & 19.82 & 2.38 & 19.32 \\
\hline WAWASAN & KJ33 & 28.57 & 41.47 & 23.68 & 15.27 & 24.34 \\
\hline USJ21 & KJ34 & 16.96 & 51.92 & 22.77 & 8.01 & 22.1 \\
\hline ALAM MEGAH & KJ35 & 29.28 & 44.74 & 20.43 & 5.67 & 20.24 \\
\hline
\end{tabular}

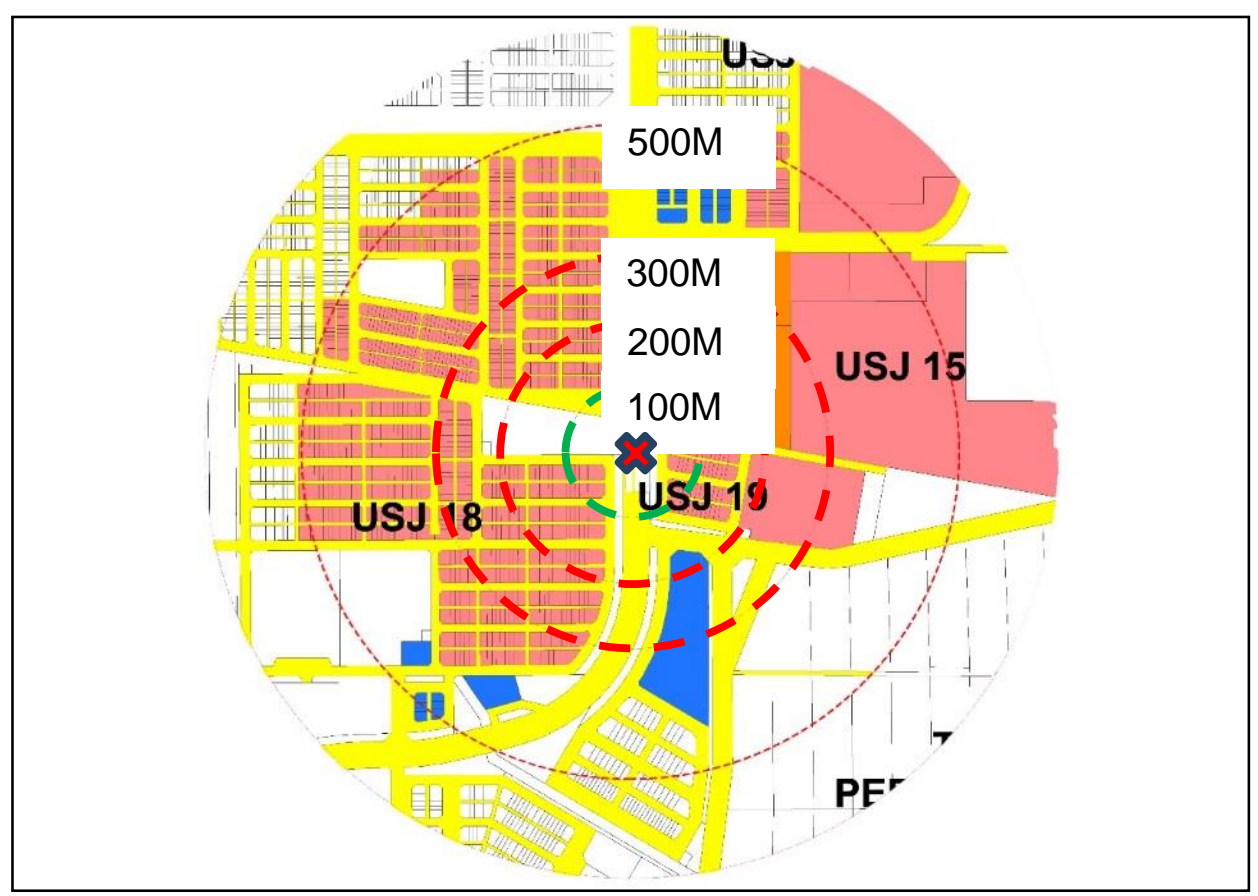

Figure 2: Land use distribution at Wawasan LRT station 


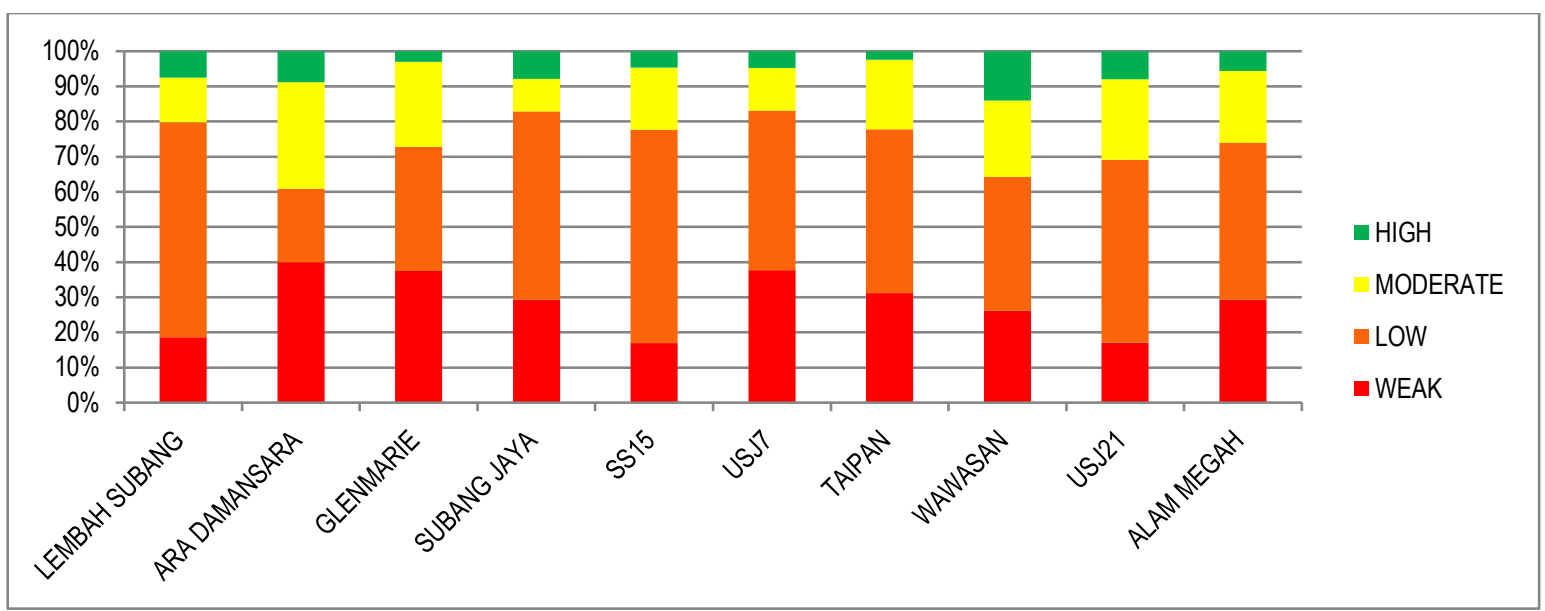

Figure 3: Distribution of urban land use around LRT stations Source: own survey

\subsection{Ridership}

Data of ridership were collected by manually counting the passengers entering and leaving the ten selected stations during the 4 hour period, which were 8 am till 10 am and 12 noon until $2.00 \mathrm{pm}$. Both categories are inbound and outbound were counted. Unlike the LUPTAI numbers, there seems to be a wide discrepancy in ridership among the stations. Generally, stations with commercial and mixed commercial and residential use tend to have much higher ridership compared to stations surrounded mostly by residential land use. This is perhaps because the commercial area tends to attract more people especially if it is also a place of employment.

Table 4: Numbers of ridership

\begin{tabular}{|c|c|c|c|c|c|}
\hline \multirow{3}{*}{ STATION NAME } & \multirow{3}{*}{ STATION NO } & \multirow{3}{*}{ DOMINANT LAND USE } & \multirow{3}{*}{ INBOUND RIDERSHIP } & \multirow{3}{*}{$\begin{array}{l}\text { OUTBOUND RIDERSHIP } \\
\text { TOTAL RIDERSHIP OUT }\end{array}$} & \multirow{3}{*}{ TOTAL } \\
\hline & & & & & \\
\hline & & & & & \\
\hline LEMBAH SUBANG & KJ 25 & RESIDENTIAL BASE & 2,521 & 1,136 & 3,657 \\
\hline ARA DAMANSARA & KJ 26 & COMMERCIAL BASE & 3,133 & 1,322 & 4,455 \\
\hline GLENMARIE & KJ 27 & COMMERCIAL BASE & 2,767 & 1,165 & 3,932 \\
\hline SUBANG JAYA & KJ 28 & COMMERCIAL BASE & 4,634 & 3,344 & 7,978 \\
\hline SS15 & KJ 29 & $\begin{array}{l}\text { COMMERCIAL AND } \\
\text { RESIDENTIAL BASE }\end{array}$ & 2,241 & 1,841 & 4,082 \\
\hline USJ7 & KJ 31 & $\begin{array}{l}\text { COMMERCIAL AND } \\
\text { RESIDENTIAL BASE }\end{array}$ & 1,923 & 1,049 & 2,972 \\
\hline TAIPAN & KJ 32 & RESIDENTIAL BASE & 1,640 & 683 & 2,323 \\
\hline WAWASAN & KJ 33 & RESIDENTIAL BASE & 1,300 & 368 & 1,668 \\
\hline USJ21 & KJ 34 & RESIDENTIAL BASE & 741 & 606 & 1,347 \\
\hline \multirow[t]{2}{*}{ ALAM MEGAH } & KJ 35 & FACILITIES BASE & 1,341 & 319 & 1,660 \\
\hline & TOTAL & & 22,241 & 11,833 & 34,074 \\
\hline
\end{tabular}

\subsection{Relationship between LUPTAl and Ridership}

Table 4 and Figure 4 try to determine if there is a simple relationship between LUPTAl and ridership. It is expected that a station with a high LUPTAl is likely to generate a high ridership figure. However, as can be seen from Figure 4, there does not seem to be a close relationship between LUPTAI and total ridership. Stations with higher LUPTAI figures such as Wawasan, USJ 21, and Alam Megah reported a lower number of riders compared to stations with slightly lower LUPTAI such as Subang Jaya, SS15, and Ara Damansara. Subang Jaya has a very high ridership since the station is connected to a KTM commuter station, resulting in a high number of people using the station.

Table 5: Total Ridership and Station LUPTAI Index

\begin{tabular}{lcccc}
\hline STATION NAME & STATION NO & $\begin{array}{c}\text { STATION } \\
\text { AREA BASE }\end{array}$ & $\begin{array}{c}\text { TOTAL } \\
\text { RIDERSHIP }\end{array}$ & $\begin{array}{c}\text { LUPTAI } \\
\text { INDEX }\end{array}$ \\
\hline LEMBAH SUBANG & $\mathrm{KJ} 25$ & RESIDENTIAL BASE & 3,657 & 20.88 \\
\hline ARA DAMANSARA & $\mathrm{KJ} 26$ & COMMERCIAL BASE & 4,455 & 20.79 \\
\hline GLENMARIE & $\mathrm{KJ} 27$ & COMMERCIAL BASE & 3,932 & 19.19 \\
\hline
\end{tabular}




\begin{tabular}{llccc}
\hline SUBANG JAYA & KJ 28 & COMMERCIAL BASE & 7,978 & 19.55 \\
\hline SS15 & KJ 29 & $\begin{array}{c}\text { COMMERCIAL AND } \\
\text { RESIDENTIAL BASE }\end{array}$ & 4,082 & 20.98 \\
\hline USJ7 & KJ 31 & COMMERCIAL AND & 2,972 & 18.37 \\
\hline TAIPAN & KJ 32 & RESIDENTIAL BASE & 2,323 & 19.32 \\
\hline WAWASAN & KJ 33 & RESIDENTIAL BASE & 1,668 & 24.34 \\
\hline USJ21 & KJ 34 & RESIDENTIAL BASE & 1,347 & 22.1 \\
\hline ALAM MEGAH & KJ 35 & FACILITIES BASE & 1,660 & 20.24
\end{tabular}

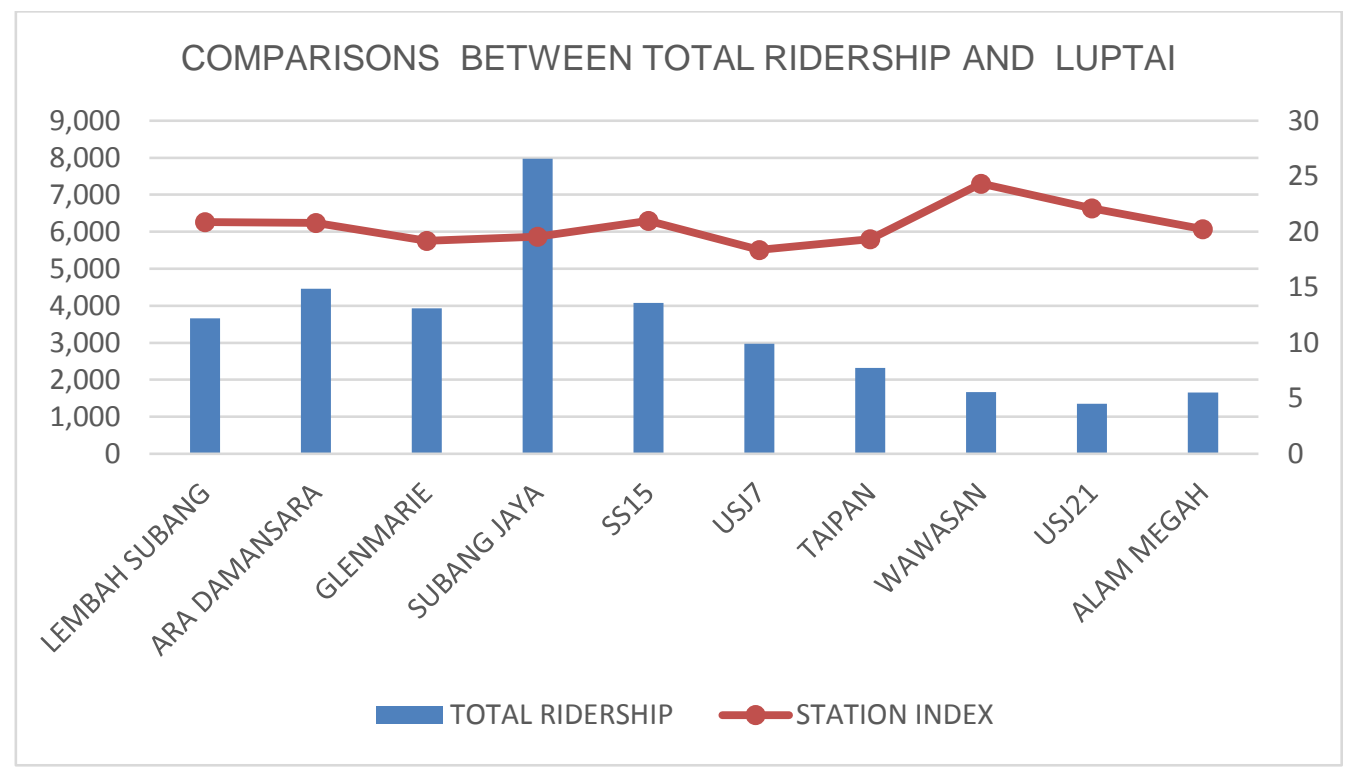

Figure 4: Comparisons between ridership and LUPTAI

\subsection{Discussion}

The analysis performed on the data collected has produced two main findings - high LUPTAl figures do not necessarily translate into high ridership and stations with dominant commercial land use have higher ridership than stations with dominant residential land use even though the latter has higher LUPTAl figures. The first finding, that high LUPTAl figures do not translate into high ridership, which is against the theory of TOD, is perhaps due to two reasons. The first is that all stations have LUPTAl figures which do not differ much from one to another. Almost all stations have LUPTAI of 19 and 20 since all areas around the stations have been developed as commercial and/or residential development. Even the highest LUPTAI at 24 (Wawasan station) is not much higher compared to other LRT stations. Thus, all the stations could be considered as having some elements of TOD, especially those in commercial or high-density residential areas.

A stronger predictor of ridership is commercial or a combination of commercial and residential land use around the LRT stations. Subang Jaya, Ara Damansara, Glenmarie, and SS15 tend to be dominated by commercial land use and have higher ridership figures. Commercial areas tend to attract people who do not live in the areas to shop or work there. Areas dominated by residential land use such as Wawasan, USJ21, and Alam Megah tend to have lower ridership since some residents rely on their automobiles as well. Subang Jaya has very high ridership due to its location in the commercial area and having both LRT and KTM commuter station in the same place. Thus, a more accurate LUPTAI calculation would be one where the commercial area is given higher weightage in the calculation of LUPTAI compared to the residential area, perhaps 1.5 for the commercial area to 1.0 for the residential area. As it is, the higher weightage is given based on distance from the station, not the type of urban land use.

\subsection{Limitations of Study}

The study has a few limitations. The first is that the number of ridership is based on a survey by researchers during the four hours on a weekday, not the whole 24 hours period. People are likely to use LRT stations in commercial areas during the weekend and off-peak hours. Thus, this may affect the number of ridership. The second limitation is that the land use classification is too simplistic and does not consider the intensity of uses. This is especially so since stations with TOD designation are likely to have received higher plot ratio or density compared to non -TOD stations although the land use remains the same. The third limitation is perhaps in the assumption 
that commercial and residential areas generate the same number of ridership, thus giving each land use the same weightage. Perhaps these limitations have impacted the findings of the study.

\subsection{Conclusion and Recommendations}

The study finds that there is no conclusive relationship between LUPTAI and ridership for the tenLRT stations selected. This is perhaps due to the fact LUPTAl figures for all stations do not differ much among them since they are based on land use classifications commercial, residential, and public facilities - around all stations and do not consider the intensity of use. However, stations with commercial or a combination of commercial and residential land use tend to have higher ridership figures. It should be noted that apartments on commercial land which are common around LRT stations are classified as commercial. Thus, a good mix of land use with higher plot ratio and density, the main component of TOD, would lead to higher transit ridership. A revised LUPTAl calculation that gives higher weightage to commercial development, detailed analyses of the intensity of land use as well as official ridership data from Prasarana should be carried out for future researches on this topic.

\section{Acknowledgments}

The authors would like to thank UiTM for providing the MITRA grant for this research. Much appreciation to Prasarana Malaysia for allowing researches to conduct enumeration and interviews at the ten selected stations.

\section{References}

Aditya, V Sohonia, Thomasa, M., Krishna Rao, K.V., (2016), Application of the concept of transit-oriented development to a suburban neighborhood, World Conference on Transport Research - WCTR 2016 Shanghai. 10-15 July 2016.

Buang, S. (2018). Embracing transit-oriented development. Retrieved December 5, 2018,

from https://www.nst.com.my/opinion/ columnists/2018/04/352335/embracing-transit-oriented-development.

Campanella, M., Halliday, R., Hoogendoorn, S., and Daamen, W., "Managing large flows in metro stations: Lessons learned from the new year celebration in Copacabana," in Proceedings of the 16th International IEEE Annual Conference on Intelligent Transportation Systems (ITSC 2013), 2013, vol. 7, no. 1, pp. 103-113

Chan, S., \& Miranda-Moreno, L. (2013). A station-level ridership model for the metro network in Montreal, Quebec. Canadian Journal of Civil Engineering, 40(3), $254-262$.

Ding, C., Liu, C., Zhang, Y., Yang, J., Wang, Y., (2017a). Investigating the impacts of the built

environment on vehicle miles traveled and energy consumption: differences between commuting and non-commuting trips. Cities $68,25 \mathrm{e} 36$

Langlois, M.; Wasfi, R.A.; Ross, N.A.; El-Geneidy, A.M, (2016). Can transit-oriented developments help achieve the recommended weekly level of physical activity? J. Transp. Health 2016, 3, 181-190.

Litman, T., (2016). The Hidden Traffic Safety Solution. Public Transportation. Public transportation can help save lives by reducing traffic crashes, September 2016.

Lund, H. M., R. Cervero, and R. W. Willson (2004). Travel Characteristics of Transit-Oriented Development in California. California Department of Transportation, Sacramento, 2004.

Levinson, Herbert S., (2005). The Reliability of Transit Service: An historical Perspective. Article in Journal of Urban Technology 12(1):99-118 · April 2005

Pongprasert, P., Kubota, H., (2018). TOD residents' attitudes toward walking to transit station: a case study of transit-oriented developments, TODs) in Bangkok, Thailand. J. Modern Transp. 29 (1), 39-51.

Sung, H., \& Oh, J.-T. (2011). Transit-oriented development in a high-density city: identifying its association with transit ridership in Seoul, Korea. Cities, 28(1): 70-82.

Transit-Oriented Development Institute, United States (2016).Benefits of Transit-Oriented Development

Tay, H. (2012). Cycling Infrastructure as a First Mile Solution for Mass Transit Access in Singapore -A Study of MRT Ridership in Singapore Towns. Master's thesis. Department of Urban Studies and Planning, Massachusetts Institute of Technology, Cambridge, MA.

Yigitcanlar T., Sioe, N., Evans, R. \& Pitot, M. (2007). A GIS-based land use and public transport accessibility indexing model. Australian Planner, 44(3), 30-37.

Yuxin H, Yang Z \& Kwok Leung Tsui (2018). An Analysis of Factors Influencing Metro Station Ridership: Insights from Taipei Metro, 2018 21st International Conference on Intelligent Transportation Systems (ITSC) Maui, Hawaii, USA, November 4-7, 2018 